\title{
EXPERIENCES OF WIDOWHOOD AND BELIEFS ABOUT THE MOURNING PROCESS OF THE BATSWANA PEOPLE
}

\author{
Ms ME Manyedi
}

M Cur student, Potchefstroom University for Christian Higher Education

Lecturer, Department of Nursing, University of the North West

\section{Prof. MP Koen \\ D Cur \\ Professor, School of Nursing Science, Potchefstroom University for Christian Higher Education}

\author{
Prof. M Greeff \\ D Cur \\ Director, School of Nursing Science, Potchefstroom University for Christian Higher Education \\ Corresponding author: vpkmg@puknet.puk.ac.za
}

Keywords: widow; widowhood; mourning process; experience; belief; community

\begin{abstract}
The loss of a partner is viewed by most authors as more serious than that of a parent or child, because of the closeness of the relationship between the husband and wife. In the South African context, and among the Batswana people in particular, widowhood is further complicated by their cultural beliefs and customs which may lead to a stressful experience for the widow. The focus of this study was on the Batswana people, the purpose of which was to explore and describe the widow's experience of widowhood as well as the community's beliefs about widowhood and the mourning process. The research was qualitative, explorative and descriptive. Data were collected by indepth interviews with the widows as well as semi-structured interviews with community members. Participants were drawn from the Mafikeng, Lichtenburg and Zeerust area in the North West Province in South Africa. Data analysis was done by open coding as described by Tesch (Creswell, 1994:155). The findings of the widows' experience of widowhood resulted in five major categories summarised as: experience of isolation due to stigmatisation of widowhood; a stressful life due to customs prescribed by society; hopelessness as a result of the loss of a husband; support provided by support systems; and over-responsibility. The community members' beliefs resulted in four major categories, namely: perceptions about the effects of the mourning process; the community's beliefs about the Batswana customs; the need to support the widow; and the mourning process as discrimination against women. Conclusions reached were that the widow is subjected to isolation, stigmatisation and stress whereas the community believes that the widow should follow culture in order to protect herself and the community. Guidelines were formulated for psychiatric nurses to facilitate the development of support mechanisms through which the community can be mobilised to assist the widow during widowhood and the mourning process.
\end{abstract}

\section{OPSOMMING}

Die verlies aan 'n lewensmaat word oor die algemeen deur outeurs as 'n groter verlies as dié van 'n ouer of 'n kind beskou. Dit word toegeskryf aan die noue verband wat tussen man en vrou bestaan. In die Suid-Afrikaanse konteks, en spesifiek in die Batswana-gemeenskap, word weduweeskap dikwels deur kulturele gelowe en gewoontes gekompliseer, wat tot spanningsvolle ervarings vir die weduwee mag lei. In hierdie studie was die fokus op die Batswanagemeenskap en veral met die oog op twee aspekte, naamlik die weduwee se belewenis van haar weduweeskap en die gemeenskap se oortuigings en gebruike met betrekking tot die rouproses. Die navorsing was kwalitatief, verkennend en beskrywend van aard. Inligting is ingewin deur indiepte onderhoude met die weduwees en semi-gestruktureerde onderhoude met lede van die gemeenskap. Deelnemers was afkomstig 
van Mafikeng, Lictenburg en Zeerust in die Noordwes Provinsie in Suid-Afrika. Die inligting is ontleed met behulp van oop kodering soos deur Tesch (Creswell, 1994:155) uiteengesit. Die bevindinge in verband met die weduwee se belewenis van haar weduweeskap kan in vyf hoofkategorieë saamgevat word, naamlik: 'n ervaring van isolering te wyte aan die stigmatisering van weduweeskap; 'n spanningsvolle leefwyse te wyte aan die gemeenskapsgebruike; hulpeloosheid as gevolg van die verlies van die eggenoot; 'n gebrek aan genoegsame ondersteuning deur ondersteuningsisteme; en 'n oordrewe gevoel van verantwoordelikheid. Die oortuigings en gebruike van die gemeenskap kan in vier hoofkategorieë saamgevat word, naamlik persepsies oor die gevolge van die rouproses; oortuigings in verband met die gebruike en tradisies van die Batswana; die noodsaaklikheid van ondersteuning van die weduwee; en die rouproses as diskriminerend teenoor die vrou. Gevolgtrekkings wat gemaak is, dui op die isolering van die weduwee, stigmatisering en spanning. Dit blyk ook dat die weduwee, as gevolg van die gemeenskap se siening en toepassing van gebruike, vind dat sy vereensaam en voel dat daar teen haar gediskrimineer word. Riglyne is vir psigiatriese verpleegkundiges daargestel met die doel om ondersteuningsmeganismes te fasiliteer wat die gemeenskap kan mobiliseer om die weduwee tydens haar weduweeskap en rouproses te ondersteun.

\section{INTRODUCTION AND PROBLEM STATE- MENT}

The loss of a partner is considered by Littlewood (1992:148) and Mendes de Leon, Kasl and Jacobs (1994:615) as being more serious than that of a parent or child. Contributing to this seriousness is believed to be the closeness of the relationship between the wife and husband. Flint (1990:11) found that most women spend their final years of life as widows because they survive husbands of their age by at least four years. In South Africa, the situation has been aggravated by the taxi and political violence in the early nineties especially among black men (Makharamedzha, 1998:18). This leads to an increase in the number of widows, with subsequent difficulties associated with widowhood and the mourning process, such as social isolation, single parenthood and being stigmatised by society (Mendes de Leon, Kasl \& Jacobs, 1994:614).

Additionally, widowhood is often a complicated experience for the widow, owing to the cultural beliefs and traditions within different communities. Batswana widows specifically seem to be discriminated against because of the cultural beliefs associated with widowhood and the mourning process. Amongst these traditions is the wearing of black mourning clothing for up to a year to be distinguishable to prevent men approaching them for a sexual relationship. The widow is also restricted from participating in activities such as attending public gatherings like funerals, parties, weddings and church services, as well as from visiting neighbours, relatives or friends (Pauw, 1990:76). The widow is further isolated due to the community's beliefs that she may contaminate other people with bad luck. It seems therefore that the widow lacks support from the community.

The subjective experience of the researcher, a psychiatric nurse and Motswana woman herself, confirms that widows seem not to get the necessary support from friends, relatives and neighbours. She also realised that because of the evident discrimination and the isolation that the widow encounters, her experience of the mourning process and the community's beliefs are not consistent, thus predisposing her to possible poor mental health. She was further motivated to explore this situation since the National Health Policy (ANC, 1994:44) stresses the need to promote women's health.

\section{RESEARCH OBJECTIVES}

In view of the above-mentioned concerns the following objectives were set for the study:

- to explore and describe the Batswana widow's experience of widowhood and the mourning process;

- to explore and describe the Batswana community's beliefs about widowhood and the mourning process; and

- to formulate guidelines for psychiatric nurses in order to facilitate the development of support mechanisms through which the community can be mobilised to assist the widow dur- 
ing widowhood and the mourning process.

\section{PARADIGMATIC PERSPECTIVE}

The research was conducted within meta-theoretical, theoretical and methodological parameters.

The Nursing for the Whole Person Theory (Oral Roberts University, Anna Vaughn School of Nursing, 1990:136-142), which is based on a Judeo-Christian philosophy, formed the grounding of the metatheoretical statements of the research. This theory was adopted because of its congruence with the researcher's philosophy. Meta-theoretical statements were formulated regarding the person, mental health, the environment and nursing. According to these meta-theoretical statements the widow, as a person, is viewed holistically and in interaction with the Batswana community with regard to widowhood and the mourning process. The study focused on the mental health of the Batswana widow. The Batswana widow's experience of widowhood and the mourning process forms part of her internal environment, while the community's beliefs about widowhood and the mourning process form part of her external environment. The focus is on psychiatric nursing and the formulation of guidelines for psychiatric nurses with the aim of facilitating the development of support mechanisms through which the community can be mobilised to assist the widow during widowhood and the mourning process.

Theoretical statements of this research included the central theoretical argument as well as conceptual definitions of the core concepts applicable to this study namely widow, widowhood, mourning process, experience, belief and community. A widow is seen as a woman who has lost her husband through death and is not remarried (Brandford, 1994:115). In this study the focus was upon Batswana females within the first twelve months of widowhood. Furthermore, widowhood is perceived as a state of mourning of a woman who has lost her husband through death and has not been remarried (Brandford, 1994:115). In this study, widowhood was thus considered a state of mourning among Batswana widows within the first twelve months after they have lost their husbands through death. The mourning process was described as the actions and manner of expressing grief, which often reflects the widow's practices of her culture (Stroebe, Stroebe \& Hansson, 1993:5), in this case the Batswana culture.

Experience is seen as an observation of, or practical acquaintance with facts or events (Brandford, 1994:322) that surround the experience of widowhood. The widow's practical acquaintance with widowhood and the mourning process as well as her perceptions of the community's attitudes form her experience of widowhood and the mourning process. Popenoe's (1995:365) definition for beliefs, namely the meaning and purpose of rituals, was adopted for this research. An individual's beliefs influence his/her attitude towards a situation. In this study the focus was on the belief system of the Batswana community with regard to widowhood and the mourning process. Community is defined as an identifiable group of people who share a common interactive pattern and geographical location (Oral Roberts University, Anna Vaughn School of Nursing, 1990:136-142). The community in this study was the Batswana people in the Mafikeng, Lichtenburg and Zeerust areas of the North West Province within South Africa.

The methodological statements were based on the Botes-model for nursing research (Botes, 1995:22).

\section{LITERATURE STUDY}

A literature study was conducted to ground the semistructured interview schedule. According to Mendes de Leon, Kasl and Jacobs (1994:615) widowhood is a state resulting from the loss of a spouse. The historical perspective of widowhood and mourning revealed that over the years there have been changes regarding causes of death, death patterns and the mourning process. In South Africa today widowhood occurs mostly as a result of violence, especially among the black population (Makharamedzha, 1998:18). Flint (1990:11) points out that men die at a considerably younger age than women do, with more widows than widowers as a result. Regarding the mourning process, Feinstein and Mayo (1990:128) as well as Sable (1992:267) emphasise that even today widows still engage in talking, remembering, regretting, appreciating and ventilating feelings as a form of coming to terms with the reality of loss. 
This reality was also studied from a cultural perspective. Rosenblatt (1993:103) argues that there are similarities in grieving across a diversity of human cultures, but that cultures differ widely in defining death and the appropriate manner of grieving. Potash (1988:160) and Pauw (1990:76) give the background of the culture of mourning among Africans. Whilst Potash (1988:160) refrains from generalising African widows because of their culture, Pauw (1990:76) confirms that specifically Batswana widows are isolated from public life during the mourning process. He clarified that in this culture, widowhood is seen as a specific state of womanhood, such as pregnancy and menstruation, which necessitates strict taboos for her. She is also seen as the man's servant, and owes her husband respect. She should be suspended from any form of activities that she might have enjoyed, like feasting, having visitors or visiting other, or enjoying radio and television programmes. Some household activities like needlework and mending are also prohibited (Pauw, 1990:84).

The concept of mourning was further studied with reference to the phases of mourning. Various authors, such as Schulz (1978:140), Kubler-Ross (1969:61) and Bowlby (in Sable, 1989:550) describe the phases of mourning. Although these authors differ slightly in their description of the phases, four major phases of mourning and grief could be identified, namely numbing, distress or shock; yearning and searching; grief and recovery; and reorganisation or "working through". Based on an overview of these phases, it was deducted that the widow manifests with grief as an emotional reaction to her loss. She furthermore expresses her widowhood and the mourning process according to her culture, in this case the Batswana culture.

When mourning does not resolve as expected, the terms abnormal, complicated, pathological or chronic grief are used as described by Glick, Parkes and Weiss (in Kastenbaum, 1977:247). Under such circumstances coping becomes necessary. Jacob (1996:284) and Weiss (in Kleinke, 1991:3) define coping as the effort made in order to manage the stressful situation. The widow, therefore, has to cope with widowhood and the mourning process within her specific cultural context.

\section{RESEARCH METHODOLOGY}

\section{Research design}

A qualitative, explorative and descriptive approach (Burns \& Grove, 1997:27) was followed to gain insight in the life experience of the widows, namely their experience of widowhood and the mourning process in the Batswana context. For the purpose of this study Batswana widows who were within the first year of mourning and community members in the Mafikeng, Lichtenburg and Zeerust area in the North West Province of South Africa were included.

\section{Research method}

The research method included sampling, data collection and data analysis.

\section{Sampling}

Two samples were drawn by means of purposive voluntary sampling, as described by Burns and Grove (1997:306). The first sample was drawn from the Batswana widows in mourning within the areas of Mafikeng, Zeerust and Lichtenburg, in the North West Province, South Africa, and the second sample was drawn from the Batswana community comprising of these widows' relatives, friends or neighbours in the same areas. The method of sampling involved approaching chiefs, headmen or councillors of the mentioned areas to request them to grant permission to conduct the research, and to identify the widows and community members who would wish to participate in the research. A list of possible participants was obtained from these authorities. The researcher then sent explanatory letters to those on the list who met inclusion criteria, and obtained informed consent from them. The following inclusion criteria were used:

Widows must have:

- been married to Batswana husbands and living in one of the areas of Mafikeng, Lichtenburg or Zeerust in the North West Province of South Africa;

- been within their first twelve months of widowhood;

- given consent to participate and to the use of an audiotape during the interview; and

- been able to communicate in Setswana or English. 
Community members must have:

- been Batswana and living in the same areas as the widows;

- been either close relatives, friends or neighbours of the participating widows;

- given consent to participate and to the use of an audiotape during the interview; and

- been able to communicate in Setswana or English.

\section{Data collection}

Data collection took place in two phases. Firstly, to explore the Batswana widow's experience of widowhood and the mourning process, the following two questions were asked:

- How does it feel to be a widow?

- Tell me about your mourning.

Secondly, to explore and describe the Batswana Community's beliefs about widowhood and the mourning process, semi-structured interviews were conducted. The following interview schedule was used:

1. How would you describe widowhood?

2. How would you describe the mourning process of a widow?

3. What do you see as the widow's role during widowhood?

4. What do you see as the community's role during widowhood and the mourning process of the widow?

5. What are your beliefs with regard to widowhood and the mourning process?

6. What help do you think your relative/friend/neighbour needs during her widowhood and the mourning process?

7. What help do you provide to the widow during her widowhood and the mourning process?

8. In your opinion whom do you think should assist the widow to cope with her widowhood and the mourning process?

9. How could the community support the widow during widowhood?

10. What is your attitude towards the widow?

11. What do you see as typical beliefs about the widow, widowhood and the mourning process amongst the Batswana people?

A trial run was conducted in order to test the applicability of the semi-structured interview schedules. Con- sent was obtained to interview the participants and to use audiotapes to record the interviews. Interviews were conducted at the participants' homes by the researcher, and lasted between forty-five minutes and one and a half hours. Field notes were written immediately after conducting the interviews. Interviews were conducted until a pattern of data repetition was reached, as prescribed by Woods and Catanzaro (1988:476). Data saturation was reached after interviewing eight widows and seven community members.

\section{Data analysis}

Audiotapes were transcribed verbatim and data analysis was done in accordance with the technique of open coding as described by Tesch (in Creswell, 1994:155) and Giorgi (in Omery, 1983:57). A psychiatric nurse specialist, experienced in qualitative research was appointed as an independent co-coder. A consensus discussion was held to finalise the categories.

\section{LITERATURE CONTROL}

A literature control (Creswell, 1994:24) was done in order to compare and contrast the findings of this research with similar studies.

\section{TRUSTWORTHINESS}

To ensure the trustworthiness of this study Guba's model (in Krefting, 1991:214-222) was used. The four criteria were ensured as follows: To ensure the criterion of truth value, the strategy of credibility was employed, applicability was ensured by means of the strategy of transferability, consistency by means of dependability and neutrality was ensured by confirmability. For the summary of the trustworthiness of this study see Table 1.

\section{ETHICAL ISSUES}

The researcher ensured that the participants' rights namely, the right to privacy, the right to anonymity and confidentiality, the right to fair treatment and the right to protection from discomfort and harm were considered throughout the process (Burns \& Grove, 1997:200-206). 
Table 1: Strategies to ensure trustworthiness

\begin{tabular}{|c|c|c|}
\hline STRATEGY & CRITERIA & APPLICATION \\
\hline \multirow[t]{4}{*}{ Credibility } & $\begin{array}{l}\text { Prolonged field } \\
\text { experience }\end{array}$ & $\begin{array}{l}\text { Letters to request participation delivered by } \\
\text { researcher and spending time with widows to } \\
\text { establish a trusting relationship. } \\
\text { Confirmation of appointments also done } \\
\text { personally by the researcher to strengthen the } \\
\text { relationship. Participants allowed enough time to } \\
\text { verbalise their experiences and beliefs } \\
\text { respectively. }\end{array}$ \\
\hline & Reflexibility & $\begin{array}{l}\text { Field notes were written immediately and } \\
\text { subjected to analysis. }\end{array}$ \\
\hline & Member checking & $\begin{array}{l}\text { Literature control of widowhood and the } \\
\text { mourning process was undertaken. }\end{array}$ \\
\hline & Interview technique & $\begin{array}{l}\text { Researcher trained on research methods and on } \\
\text { interviewing skills. } \\
\text { Research supervised by experienced experts in } \\
\text { qualitative research. }\end{array}$ \\
\hline \multirow[t]{2}{*}{ Transferability } & Selection of sample & $\begin{array}{l}\text { The sampling method was purposive and } \\
\text { voluntary. } \\
\text { Neutral persons (chiefs, headmen or councillors) } \\
\text { were asked to initially identify potential } \\
\text { participants. }\end{array}$ \\
\hline & Dense description & $\begin{array}{l}\text { Through description of research methodology; } \\
\text { literature control of the findings. }\end{array}$ \\
\hline \multirow[t]{4}{*}{ Dependability } & Stepwise replication & Co-coder involved in independent data analysis. \\
\hline & Dense description & Detailed description of the methodology. \\
\hline & $\begin{array}{l}\text { Code-recode } \\
\text { procedure }\end{array}$ & $\begin{array}{l}\text { Data analysed twice and results compared. } \\
\text { Consensus discussion held with co-coder. }\end{array}$ \\
\hline & Peer examination & $\begin{array}{l}\text { Expert supervision provided (the supervisors are } \\
\text { experts in qualitative research and psychiatric } \\
\text { nursing science). }\end{array}$ \\
\hline \multirow[t]{2}{*}{ Confirmability } & Confirmability audit & $\begin{array}{l}\text { Done throughout the research by supervisors of } \\
\text { the research. }\end{array}$ \\
\hline & Reflexibility & Field notes taken and subjected to data analysis. \\
\hline
\end{tabular}

\section{DISCUSSION OF FINDINGS}

The findings resulted in five major categories concerning the widow's experience of widowhood and the mourning process (summarised in Table 2), and four major categories concerning the community's beliefs about widowhood and the mourning process (summarised in Table 3). The following is a brief discussion of the findings. 


\begin{tabular}{|c|c|c|c|}
\hline COLUMN A & COLUMN B & COLUMN C & COLUMN D \\
\hline $\begin{array}{l}\text { Experience feelings of } \\
\text { isolation due to the } \\
\text { stigmatisation of widowhood }\end{array}$ & $\begin{array}{l}\text { Experience of a stressful life } \\
\text { due to the customs } \\
\text { prescribed by the society }\end{array}$ & $\begin{array}{l}\text { Experience of the support } \\
\text { provided by the internal and } \\
\text { external support system }\end{array}$ & $\begin{array}{l}\text { Experiences feelings of } \\
\text { hopelessness resulting } \\
\text { from the loss of her } \\
\text { husband }\end{array}$ \\
\hline $\begin{array}{l}\text { Experiences of being shunned } \\
\text { by society due to cultural } \\
\text { beliefs associated with } \\
\text { widowhood and the mourning } \\
\text { process. } \\
\text { - Wearing of mourning clothes. } \\
\text { - Widows believed to be } \\
\text { infested with bad luck: } \\
\text { - being feared for potential } \\
\text { harm to the life of people, } \\
\text { animals and crops; } \\
\text { - people avoid contact due to } \\
\text { fear of 'contamination'; } \\
\text { - widow cooked for and } \\
\text { served } \\
\text { by another widow; and } \\
\text { - eating utensils separated } \\
\text { from the rest. }\end{array}$ & $\begin{array}{l}\text { Experiences of the need to fulfil } \\
\text { customs expected by society } \\
\text { during the mourning process. } \\
\text { - Undergoing the cleansing } \\
\text { process. } \\
\text { - The widow has the } \\
\text { responsibility to maintain } \\
\text { the in-laws' reputation: } \\
\text { - she is expected to } \\
\text { observe rules of } \\
\text { mourning as a sign of } \\
\text { self-respect; and } \\
\text { - she is expected to } \\
\text { display good behaviour } \\
\text { as a sign of respect for } \\
\text { her late husband. }\end{array}$ & $\begin{array}{l}\text { Experiences of feelings of } \\
\text { being supported during } \\
\text { bereavement. } \\
\text { - Support by own family } \\
\text { members. } \\
\text { - Support by friends, } \\
\text { neighbours and others. }\end{array}$ & $\begin{array}{l}\text { Experiences of loss of } \\
\text { emotional support of the } \\
\text { husband. } \\
\text { - The widow lacks someone } \\
\text { to talk to: } \\
\text { - relatives disappear very } \\
\text { soon after the burial; } \\
\text { - the in-laws aggravate the } \\
\text { situation with their } \\
\text { bitterness; } \\
\text { - friends and neighbours } \\
\text { are afraid to visit; and } \\
\text { - the widow experiences } \\
\text { emotional pain due to } \\
\text { loss of love: } \\
\text { * she will never see nor } \\
\text { enjoy his company again; }\end{array}$ \\
\hline
\end{tabular}




\section{Experience a sense of being}

imprisoned due to discriminatory restrictions.

- The widow is required to stay indoors for a specific period:

* she is not allowed to move freely;

* she is not allowed to visit other households; and

* when compelled to leave home she is allowed to go to

\section{Experience of disruption of}

family relationships.

- The widow is blamed for the death of her husband.

- The in-laws take control of the situation by: - making too many prescriptions;

- uttering negative statements; and - demanding to be given

\section{and}

* she has nobody to share domestic responsibilities with.

- The widow experiences difficulty in accepting the loss of her husband.

- The widow experiences emotional outbursts.

\section{Experience of spiritual}

support based on strong

Christian beliefs.

- The belief that everything has been planned by God.

- Reassurance that God will take care of the situation.

The widow's trust in the church as a strong

\section{Experiences feelings of}

unworthiness due to the loss of a father figure.

- Loss of dignity and feelings of inadequacy:

- she feels light and empty; - she feels insecure and unprotected; and - she experiences difficulty in disciplining the children. 


\begin{tabular}{|c|c|c|c|}
\hline $\begin{array}{l}\text { a particular place only and go } \\
\text { straight home. } \\
\text { - The widow is restricted from } \\
\text { performing certain activities } \\
\text { and social roles: } \\
\text { - she is not supposed to attend } \\
\text { social gatherings; } \\
\text { - she must be home before } \\
\text { sunset to light a candle in her } \\
\text { bedroom; } \\
\text { - she is not supposed to get } \\
\text { involved in relationships with } \\
\text { men; } \\
\text { - she is not expected to talk to } \\
\text { people freely; and } \\
\text { - the mourning clothes are } \\
\text { washed only at night. }\end{array}$ & part of the estate. & support system. & $\begin{array}{l}\text { - Experience of stress-related } \\
\text { symptoms: } \\
\text { - psychological symptoms; } \\
\text { and } \\
\text { - physical symptoms. } \\
\text { - Experience of loss of financial } \\
\text { security: } \\
\text { - she fears future financial } \\
\text { survival due to loss of } \\
\text { breadwinner; and } \\
\text { - she fears for the future } \\
\text { education of her children. }\end{array}$ \\
\hline
\end{tabular}




\section{Discussion of the findings concerning the widow's experience of widowhood and the mourning process}

Following is a discussion of major and sub-categories of the widow's experience of widowhood and the mourning process as summarised in Table 2 .

\section{Experience of feelings of isolation due to the stigmatisation of widowhood}

It was identified that the Batswana widow was subjected to isolation due to being stigmatised by society. The isolation and stigmatisation were evident in the widows' statements of being shunned by society because of the cultural beliefs associated with widowhood and the mourning process. One of these beliefs is that widows are expected to wear black mourning clothes. The widows expressed that they felt uncomfortable in the black attire, as stigmatisation was perceived to be due to the black clothing. It made her distinguishable from other people and some would prefer other colours just to decrease the stigma. The following quotation relates to this finding: "Some of the friends start to stay away from you because of the 'rou', the mourning garments that you are wearing; these black garments, when you go to the taxis people do not want to sit next to you."

Another belief is that the widow is infested with bad luck ("sefifi"), which could harm specifically small babies and crops. People avoid contact with the widow due to fear of contamination. Because of this belief the widow is cooked for and served by another widow and her eating utensils are separated from the rest.

The isolation and stigmatisation also appeared to give rise to the experience of imprisonment due to discriminatory restrictions. The widow is confined to her home for a specific period, and may only leave home for matters that require her personal attention such as dealing with the estate of the deceased. It is believed that she will spread the bad luck that she is believed to be having. She is also restricted from performing certain activities and social roles. These include that the widow is not supposed to attend social gatherings, the widow must be home before sunset to light a candle in her bedroom, she is not supposed to get involved in relationships with men or to talk freely to people and she may only wash the mourning clothes at night. The imprisonment expressed by these widows was evident in statements such as: "I must just stay home, it means I am in prison." "I am not supposed to visit any house and I cannot talk to people."

Van den Hoonaard (1994:124) and Parkes (1986:178) similarly mention a finding, namely that in the Jewish custom the widow is expected to "sit shiva" for a certain period after the death of a husband. The confirmation of the widow's experience of imprisonment is also similar to the findings in the study conducted by Pauw (1990:80) who states that the widow is admitted ceremonially to every household that she wishes to visit.

\section{Experience of a stressful life due to the customs prescribed by society}

A stressful life is experienced due to the customs that the community expects the widow to follow as well as by her experience of disrupted family relationships. Amongst the customs, the widow is expected to undergo the cleansing process that involves taking herbs to neutralise the 'bad luck'. A widow expressed herself in the following manner: "So they brought somebody who came to cleanse me and give me those traditional herbs, took me to the cross roads because I gave in, wanting to go to work."

The widow is furthermore expected to maintain her own and the family's reputation by observing the rules of mourning as a sign of respect and to display good behaviour in respect of her late husband. Some widows therefore followed the rules even if they did not believe in culture for the sake of maintaining the family dignity.

Further stress is caused by the disruption of family relationships, which results from being blamed for the death of the husband. This common practice among the Batswana people adds to the grief of the widow. One of the quoted statements by the widows sums it up: "... the in-laws can frustrate you; they have a lot to say and according to our belief the blacks, when the husband dies the wife has contributed, but when the wife dies no, it is normal."

Owing to the disrupted relationships, the in-laws take control of the situation by making too many prescrip- 
tions regarding the mourning process, uttering negative statements and demanding to be given part of the estate.

Pauw (1990:79), Frude (1991:345) as well as De Garmo and Kitson (1996:994) support these findings, specifically that these beliefs are shared by most black South Africans. Lopata (1988:115) confirms the deterioration of the widow's relationship with her in-laws after the death of her husband.

\section{Experience of the support provided by the internal and external support systems}

The widows who participated in this study reported that their own families supported them financially as well as emotionally. In the widow's own family, the uncle plays an important role in carrying out mourning rituals, for example, the cleansing ritual. Friends, neighbours and other community members form an external support system. They help with household tasks and comfort the bereaved. The following are direct quotations: "The support you will get it from your own parents, but the in-laws, ooh!" "Yes I mean neighbours, friends and church members, they often come to me, they check on me and as we talk I forget".

Bankoff (1983:831) and Lopata (1988:116) support the view that own family members or parents can offer support during the early period of bereavement.

The widows furthermore felt strengthened by spiritual support based on their strong Christian beliefs. They believe that God is in control and their comforter, and that He would take them through the grief. The widows interviewed for this study also mentioned how effective the spiritual support they received from the church was during their bereavement. Siegel and Kuykendall (1990:130) also found that widows belonging to a church experienced less impact of loss, and that such external support systems have a positive impact on the outcome of bereavement.

\section{Experience of feelings of hopelessness resulting from the loss of the husband}

It became evident during the interviews that widows experience loss of emotional support of their husbands, as well as feelings of unworthiness due to the loss of a father figure. The experience of loss of emotional support is due to the fact that the widow needs someone to talk to, but that relatives disappear very soon after the burial, and her children cannot replace her husband to fulfil this need. The in-laws aggravate the situation with their bitterness, and because of the mourning customs, friends and neighbours are afraid to visit. The widow experiences emotional pain due to the fact that she will never see nor enjoy her husband's company again, and that she has nobody to share domestic responsibilities with. She has difficulty in accepting his death, and experiences denial, dreams of seeing him alive and imaginations. This causes the widow to experience emotional outbursts: "It is not that even now my tears ran dry, at times I do cry bitterly, but crying alone ...".

Widows also reported feelings of unworthiness due to the loss of a father figure. Widows feel inadequate due to the loss of someone who gave them dignity and a sense of worth. They feel insecure and unprotected. Additionally, the widow experiences difficulty in disciplining her children, because they are not used to her being dominant in enforcing discipline and tend not to take note of what she says. In the Batswana context the husband usually maintains discipline in the family. The widow also experiences a loss of financial security. She fears future financial survival due to the loss of her husband's financial support as breadwinner, and is concerned about the future education of her children. The widow consequently experiences psychological, as well as physical stress-related symptoms such as depressive symptoms, headaches and back pain. The following quote demonstrates the widow's feelings of unworthiness: "to think as if everybody seeing you perceives you as a paper, as if you are no longer worth anything."

Jacob (1996:281) and Cowles (in Jacob, 1996:288) support that loss of a partner leads to a significant impact of emotional loss. Eells, Fridhandler and Horowitz (1995:270) also confirm that loss of a spouse is traumatic because it also entails loss of an economic partner, companion and fellow parent.

\section{Experience of a sense of over-responsi- bility due to the absence of partner}

The widows' major concern in this regard was that the disruption in family life caused by their husbands' death was difficult for them to manage. It is typical of the Batswana culture that certain family matters are at- 
tended to by a husband. The widow now lacks someone to share important family matters with, such as education, marriage of her children and discipline. She also experiences difficulty in maintaining household property and livestock. The widow's experience of problems related to caring for livestock seems to be unique to this research. The following citation illustrates the feelings of over-responsibility: "Ja, some of the frustrations really is that he was one man who used to do most of the things and I was sort of depending on him ..., from here now everything is just on my shoulders."

Holmes and Rahe (in Stroebe et al. 1993:196) as well as Pellman (1992:253) confirm that death of a spouse requires maximum readjustment in the roles of the widow.

This completes the discussion of the Batswana widow's experience of widowhood and the mourning process. Following is the Batswana community's perceptions about widowhood and the mourning process.

\section{Discussion of findings concerning the community's beliefs about widowhood and the mourning process of the Batswana people}

These findings will be discussed according to Table 3.

The four major categories of the community's beliefs about the mourning process will be briefly discussed.

\section{Perceptions about the effects of the mourning process}

Community members acknowledged that the widow indeed experiences emotional stress as an effect of losing a companion. Her grief is also acknowledged. They also express concern about her loneliness that is caused by the loss of emotional support from her husband. They observe that the widow finds it difficult to accept her husband's death. These findings are reflected in the following quotation: "It is a period of loneliness as I observed those affected because one was used to living with the husband, now when she is alone it is really a lonely period."
The community members furthermore perceived that the widow's role is now two-fold because of the absence of a male figure in the house. Firstly, she has to continue with her role, which is disturbed by her grief, and secondly, she has to assume the paternal role which the community members observed she was not coping with. This can be deduced in the following statement: "Her husband ... was a person who used to do many things for her. Now what I have noticed is that those things are facing her."

The literature confirms these findings. The sense of loss as perceived by community members is confirmed by Eells et al. (1995:270) who point out that it is stressful due to the multiple roles that spouses play in each other's lives. Kleinke (1991:131) confirms that people do experience grief after the loss of a loved one. The widow's loneliness and loss of emotional support is confirmed by Adolph (1996:25). Her difficulty to accept her husband's death might be part of one of the initial phases of mourning, as confirmed by Horowitz (in Eells et al. 1995:272). Parkes and Weiss (1983:1) indicate that grief has an impact on the roles of the affected person, which confirms the perception of the community members regarding the change in the roles of the widow.

Most community members additionally perceived that the widow's role is confused by the customs that she is expected to follow during the mourning process. According to these customs she is immediately relieved of her daily responsibilities, she is expected to stay in her bedroom and not move around for a period ranging from two weeks to three months. When she is allowed to visit other households after this period, she is expected to perform certain rituals before being admitted to the household. This is done to ensure that the "bad luck" that is believed to be infested in her is neutralised. These customs restrict the widow to fulfil her role as breadwinner and parent, while she is expected to assume both her own and her husband's responsibilities at home and to attend to all domestic chores. A finding of particular interest is that some community members criticised young widows for not observing these customs, and perceived them as dangerous: "It is because young widows do not mourn, and again do not follow restrictions and rules as set ... that is why the young widows are dangerous". 


\begin{tabular}{|c|c|c|c|}
\hline$\overline{\operatorname{COL}}$ & OLUMN B & COLUMN C & COLUMN \\
\hline $\begin{array}{l}\text { Perceptions about the effects of } \\
\text { the mourning process }\end{array}$ & $\begin{array}{l}\text { rceptions about the beliefs of } \\
\text { Batswana customs that the } \\
\text { dow has to follow }\end{array}$ & $\begin{array}{l}\text { erceptions of the need to } \\
\text { upport the widow }\end{array}$ & $\begin{array}{l}\text { Percepti } \\
\text { mournin } \\
\text { discrimi }\end{array}$ \\
\hline $\begin{array}{l}\text { Perceptions of acknowledging the } \\
\text { emotional stress of the widow. } \\
\text { - Perceptions of the widow's sense } \\
\text { of the loss of a companion. } \\
\text { - The widow goes through a } \\
\text { grieving process. } \\
\text { - Perceptions of the widow's } \\
\text { loneliness: } \\
\text { - lack of emotional support; } \\
\text { - difficulty in accepting the death of } \\
\text { her husband; and } \\
\text { - perceptions of the impact of a } \\
\text { missing male figure in the house. }\end{array}$ & $\begin{array}{l}\text { Perceptions of the need to maintain } \\
\text { the name and dignity of the in-laws. } \\
\text { - The widow has to respect herself, } \\
\text { her family and society. } \\
\text { - The widow has to follow the set } \\
\text { rules: } \\
\text { - she has to dress in her mourning } \\
\text { clothes (black or navy blue); } \\
\text { - mourning clothes should be } \\
\text { washed at night; } \\
\text { - no intermingling with other } \\
\text { people, for example, at public } \\
\text { gatherings; } \\
\text { - the widow must be home at } \\
\text { sunset; and } \\
\text { - when she visits specific places } \\
\text { she has to go back straight } \\
\text { home. }\end{array}$ & $\begin{array}{l}\text { Perceptions of the widow's need to } \\
\text { be assisted during the mourning } \\
\text { process. } \\
\text { - The provision of emotional } \\
\text { support: } \\
\text { - the emotional support provided } \\
\text { by members of the family; and } \\
\text { - support provided by the } \\
\text { community members. } \\
\text { - The spiritual support provided by } \\
\text { the community: } \\
\text { - church members visit frequently; } \\
\text { and } \\
\text { - the traditional healer is } \\
\text { appointed to 'cleanse' the entire } \\
\text { household. } \\
\text { - Social and material support by } \\
\text { the society: }\end{array}$ & $\begin{array}{l}\text { - Mourn } \\
\text { attach } \\
\text { - Widow } \\
\text { moving } \\
\text { beliefs } \\
\text { - Widow } \\
\text { engag } \\
\text { men. } \\
\text { - Widow } \\
\text { of thei } \\
\text { - Strict c } \\
\text { perform } \\
\text { more p } \\
\text { - Mourn } \\
\text { men. }\end{array}$ \\
\hline
\end{tabular}




\begin{tabular}{|c|c|c|}
\hline & & $\begin{array}{l}\text { - neighbours and friends assist } \\
\text { with household chores; } \\
\text { - friends keep her company and } \\
\text { involve her in a light-hearted } \\
\text { conversation; } \\
\text { - the widow needs assistance with } \\
\text { regard to the discipline of } \\
\text { children; and } \\
\text { - the widow needs advice with } \\
\text { regard to the community's } \\
\text { expectations of her role. } \\
\text { Financial support provided by the } \\
\text { community. }\end{array}$ \\
\hline $\begin{array}{l}\text { Perceptions of the widow's role } \\
\text { being confused due to customs that } \\
\text { she is expected to follow during the } \\
\text { mourning process. } \\
\text { - The widow is immediately relieved } \\
\text { of her daily responsibilities: } \\
\text { - the widow is expected to stay in } \\
\text { her bedroom to observe the } \\
\text { mourning process; and }\end{array}$ & $\begin{array}{l}\text { Perceptions of the fear by the } \\
\text { community that the widow may } \\
\text { transfer the curse of death to them. } \\
\text { - Community members believe that } \\
\text { contact with the widow may be } \\
\text { unsafe: } \\
\text { - crossing the widow's tracks is } \\
\text { perceived as dangerous; } \\
\text { - sexual contact with the widow }\end{array}$ & $\begin{array}{l}\text { Perceptions of societal attitudes } \\
\text { towards the widow. } \\
\text { - Community members perceive } \\
\text { their attitude as positive. } \\
\text { - Society is concerned that elderly } \\
\text { people prescribed the customs } \\
\text { without grounding. } \\
\text { Society believes that the widow } \\
\text { has to follow the culture to remain }\end{array}$ \\
\hline
\end{tabular}


Literature confirms these findings and in particular Glick (in Kastenbaum, 1977:247) confirms that some widows abandon their cultural practices, giving different reasons for doing so.

\section{Perceptions about the beliefs of the Batswana customs that the widow has to follow}

Community members expressed a belief that the widow has to respect herself, her family and society by following customs based on cultural beliefs. Observance of the rules is perceived as maintaining the name and the dignity of her late husband and in-laws. These rules are: dressing in the mourning attire, washing of the mourning clothes only at night, no intermingling with other people, for example, at public gatherings, she should be home by sunset and go straight home after visiting specific places. The community fear that the widow may transfer the curse of death to them and therefore believe that contact with her may be unsafe. Crossing the widow's tracks is avoided; sexual contact with her is avoided to prevent a dreaded disease ('boswagadi') and going into the cattle kraal and mealie fields with her constitutes danger. They therefore strongly believe that the end of the mourning ceremony ("cleansing") should take place. Expressions of these beliefs can be seen in the citation: "It is like that mama, there are widows who do not put on mourning clothes and that lack of mourning kill them."

Kastenbaum (1977:244) views that society has expectations that a grieved person should mourn. It is thus possible for a bereaved person not to experience grief, but engage in cultural expressions of mourning. These views support the findings of this study because mourning seems to be externalised in the Batswana context. The society appears to be satisfied with what the widow does as expected culturally, rather than what she feels internally.

\section{Perceptions of the need to support the widow}

Although the community members felt strongly about following the mourning customs, they also saw a need to support the widow. They acknowledged that she had to be assisted through her mourning process emotionally, spiritually, socially and financially, as expressed by some members: "Support her in the way of visiting her, talking to her about pleasant things that 
won't cause her stress."

Family members support the widow emotionally by sympathising and staying with her for a period of time. Community members render emotional support by means of frequent visits. Spiritual support is given by church members and traditional healers. Social and material support include assistance with household chores, engaging in light-hearted conversations with the widow, assistance with disciplining her children and advice on the community's expectations of her role. Financial support is also given, specifically regarding the funeral and catering needs.

Several authors such as Adolph (1996:989), Farberow, Gallagher-Thompson and Gilewski (1992:120) and Kaunonen, Tarkka, Paunonen and Laippalla (1999:1307) confirm the importance of supporting the widow to overcome her grief. Community members expressed support of the widow as demonstration of a positive attitude towards her and they blamed culture for many restrictions. Some, however, believed that the widow must follow the culture: "My belief is based on the culture of our ancestors because modern things are confused."

Cultural practices are confirmed by Rosenblatt (1993:110) who states that in other cultures, a person bereaved from a spouse is expected to mourn for a lifetime.

\section{Perceptions of the widow's mourning proc- ess as discrimination against women}

Community members expressed strongly that though they believe in culture, they perceived these mourning restrictions as being applicable to women only. They believe that mourning clothes attach stigma to widows, widows are prevented to move freely and to engage in relationships with men and they are blamed for the death of their husbands. The strict cultural rituals that have to be performed inflict more pain to the widow. A further observation is that these mourning rules are not strict on men. The following statement by a community member illustrates these findings: "So really women are usually victims of this widowhood because there she is in black attire, home bound you know. In this Tswana culture I usually fail to understand whether a widower does have these restrictions."
This was also a unique finding regarding the black culture because it was only confirmed by Pauw (1990:76) whose study was conducted among blacks.

In summarising the findings of this study, the widow's experience of widowhood and the mourning process is that she is isolated, stressed due to customs and feels lonely and burdened with over-responsibility. The community members' perceptions were that the widow's mourning is stressful and aggravated by the cultural rules; they also feel strongly about the widow being discriminated against as a woman.

\section{CONCLUSIONS}

The Batswana widows seem to experience feelings of isolation due to stigmatisation, which leads to her being shunned by society. Cultural practices contribute to a sense of imprisonment with resulting stress especially due to minimal support. She also experiences hopelessness and insecurity caused by loss of her partner, which contributes to over-responsibility and having to deal with the disrupted family life.

The community seems to perceive widows as going through grief though they would not compromise cultural practices. The community members believed that the widow has to undergo rituals to cleanse her, and that she should observe the mourning process by suspending social activities. Some community members, however, perceived that the widow needs support. They also viewed the mourning process as discrimination against women, because most restrictions are applicable to widows but not to widowers.

\section{LIMITATIONS OF THE STUDY}

The limitations of the study mainly have relevance to sampling and the type of data gathered. More enlightened and suburban widows and community members were interviewed as was intended initially, as it was difficult to get co-operation from the rural-based widows and community members as they were not free to give consent. The researcher additionally suspects that some information was held back during the interviews, either because of the sensitive nature of the topic, or because participants could have thought that, because the researcher is a black person, some detail was obvious to her and needed not be explained. Information 
could also have been held back because of the belief that culture belongs to the old and uneducated and discussion of such issues tends to be avoided by younger, educated people.

\section{RECOMMENDATIONS}

Recommendations were made for nursing education, nursing research and the psychiatric nursing practice. Nursing education should aim to assist psychiatric nurses in the development of skills that will enable them to mobilise the community as a support system to support widows during widowhood and the mourning process. Nursing research should explore further issues arising from this research, for example, the willingness of the Batswana community to adjust the cultural practices related to widowhood and the mourning process. Recommendations for the psychiatric nursing practice were formulated as guidelines for psychiatric nurses to facilitate the development of support mechanisms through which the community can be mobilised to assist the widow during widowhood and the mourning process.

\section{Guidelines to facilitate the widow to han- dle mourning effectively}

From the findings and conclusions it seems that there is a need for the widow to first understand widowhood and mourning in the cultural context of the Batswana people. It may be necessary for her to learn about the customs. It will then be useful if she clarifies the following:

- values regarding customs identified as protective and acceptable to her and to negotiate with elders and community members such as the chief where necessary;

- customs unacceptable to her so that she can seek people to support her in negotiating noncompliance with such customs. She can also be made aware of her use of various defence mechanisms that she uses to escape the customs. Assertiveness should be exercised instead of using defence mechanisms; and

- it would be beneficial for the widow to identify some of the customs that are protective such as rituals leading to her admittance into other households, because it will contribute to her support.

\section{Guidelines to mobilise support mecha- nisms to counteract the widow's negative experiences of widowhood and the mourn- ing process}

- It would be helpful if psychiatric nurses create avenues whereby the widow could verbalise the adverse effects and difficulties of widowhood in order to mobilise support.

- This mobilisation of support might include addressing the position adopted by the in-laws who form her immediate family after marriage. The widow's family could be involved to mediate between their daughter and her in-laws to clarify issues like blaming her for the death of her husband.

- Psychiatric nurses could teach the community about the value of establishing and maintaining good relationships with family members, friends, relatives and neighbours all of whom are important for support during difficult times such as bereavement.

- It could be useful for the widow to clarify her spiritual needs so that by showing appreciation and acceptance of the members of her congregation visiting her during bereavement, they could be motivated to maintain those visits during her period of mourning. By clarifying both her cultural and spiritual needs she will be able to avoid confusion, thus getting the support from both support systems.

\section{Guidelines to assist the widow to restore her identity and sense of self-worth}

- Taking stock of her strengths and capabilities could boost the widow's morale thus improving her self-esteem. Professional counselling may be necessary if her sense of self-worth is seriously affected.

- New skills may have to be acquired to minimise some of the burden such as maintenance of equipment. Learning proper and healthy parenting skills could be useful to improve family interaction.

- It may be useful to establish ongoing communication with her children to address current issues within the home. By promoting such a 
healthy relationship with her children they will learn to respect her and this will result in restoration of her sense of self-worth.

\section{Guidelines to mobilise the community to support the widow}

These guidelines focus on educating the community, clarifying cultural needs and mobilising support systems:

- Educating the young generation about culture to be accepted where applicable such as during widowhood and mourning.

- The community could be requested to review the applicability of some of the customs and the conflict they may cause during current times.

- It could be of benefit if the psychiatric nurse mobilises clarification of customs between the widow's family, her in-laws, friends and neighbours so that they might provide support without hesitation.

- The church could be activated to mediate between the widow and her in-laws for a common understanding of death within religious beliefs, clarifying that it could be unjustifiable to blame her for the death of her husband.

- Psychiatric nurses should also develop counselling skills in order to intervene effectively should the widow need such help.

- Mobilisation of family support could be helpful during the critical period of mourning, such as staying with her until she overcomes her grief.

- Widow support groups could be mobilised to visit new widows to share experiences, thus strengthening her.

- It appears that there is a need for the establishment of forums between traditional leaders, elders in the community and widows where these customs and their purpose could be discussed.

- Church forums could also be facilitated to educate congregations about topics such as mourning and bereavement for better understanding.

- Psychiatric nurses could create a platform to address the issue of discrimination against women where women groups could challenge authorities through traditional leaders.

\section{SUMMARY}

The objectives of this study were achieved through exploration and description of the Batswana widow's experience of widowhood and the mourning process and of the Batswana community's perceptions and beliefs about the mourning process. Recommendations were made for nursing education, nursing research and psychiatric nursing practice with reference to specific guidelines as stated earlier in this article.

\section{REFERENCES}

ADOLPH, MR 1996: No longer an outsider: Social group worker as a client in a bereavement group for older women. Social Work with Groups, 19(2):17-33.

ANC see AFRICAN NATIONAL CONGRESS

AFRICAN NATIONAL CONGRESS 1994: The national health plan for South Africa. Lesotho: BAHR.

BANKOFF, EA 1983: Social support and adaptation to widowhood. Journal of Marriage and the Family, 45, November:827-839.

BOTES, AC 1995: A model for research in nursing. Johannesburg: Rand Afrikaans University.

BRANDFORD, W 1994: The South African pocket dictionary of current English. Cape Town: Oxford University Press.

BURNS, N \& GROVE, SK 1997: The practice of nursing research: conduct, critique and utilization; $3^{\text {rd }}$ edition. Philadelphia: WB Saunders.

CRESWELL, JW 1994: Research design: Qualitative and quantitative approaches. Thousand Oaks: Sage.

DE GARMO, DS \& KITSON, GC 1996: Identity relevance and disruption as predictors of psychological distress for widowed and divorced women. Journal of Marriage and the Family, 58:983-997. EELLS, TD; FRIDHANDLER, B \& HOROWITZ, MJ 1995: Self-schemas and spousal bereavement: Comparing quantitative and clinical evidence. Psychotherapy, 32(2):270-282.

FARBEROW, NL; GALLAGHER-THOMPSON, D \& GILEWSKI, M 1992: The role of social support in the bereavement process of surviving spouses of suicide and natural deaths. Suicide and Life-Threatening Behaviour, 22(1):107-124.

FEINSTEIN, D \& MAYO, PE 1990: Rituals for living and dying: From life's wounds to spiritual awakening. San Francisco: Harper. FLINT, L 1990: A widow's lot. Public Servant, 70(8):10-11. FRUDE, N 1991: Understanding family problems: A psychological approach. New York: John Wiley.

JACOB, SR 1996: The grief experience of older women whose 
husbands had hospice care. Journal of Advanced Nursing, 24:280-286.

KASTENBAUM, RJ 1977: Death, society and human experience.

St Louis: Mosby.

KAUNONEN, M; TARKKA, M; PAUNONEN, M \& LAIPPALLA, $P$ 1999: Grief and social support after the death of a spouse. Journal of Advanced Nursing, 30(6):1304-1311.

KLEINKE, CL 1991: Coping with life challenges. Monterey: Brooks/ Cole.

KREFTING, L 1991: Rigor in qualitative research: the assessment of trustworthiness. American Journal of Occupational Therapy, 45(3):214-222.

KUBLER-ROSS, E 1969: On death and dying. London: Tavistock. LITTLEWOOD, J 1992: Aspects of grief. London: Routledge.

LOPATA, HZ 1988: Support systems of American urban widowhood. Journal of Social Issues, 44(3):113-128.

MAKHARAMEDZHA, P 1998: Gauteng taxi violence under investigation. City Press: 18 Dec:6.

MENDES DE LEON, CF; KASL, SV \& JACOBS, S 1994: A prospective study of widowhood and changes in symptoms of depression in a community sample of the elderly. Psychological Medicine, 24(3): 613-624.

OMERY, A 1983: Phenomenology: a method for nursing research. Advances in Nursing Research, 5(2): 49-63.

ORAL ROBERTS, ANNA VAUGHN SCHOOL OF NURSING 1990: Self-study report, submitted to the council of Baccalaureate and Higher Degree Programs, National League for Nursing, Vol. 1. Narrative by criteria. Tulsa: Oklahoma.

PARKES, CM 1986: Bereavement: studies of grief in adult life. London: Tavistock.

PARKES, CM \& WEISS, RS 1983: Recovery from bereavement. New York: Basic Books.

PAUW, BA 1990: Widows and rituals danger in Sotho and Tswana communities. African Studies, 49(2):79-99.

PELLMAN, J 1992: Widowhood in elderly women: Exploring its relationship to community integration, hassles, stress, social support, and social support seeking. International Journal of Aging and Human Development, 35(4):253-264.

POPENOE, D 1995: Sociology; $10^{\text {th }}$ edition. Englewood Cliffs: Prentice Hall.

POTASH, B 1988: Widows in African Society. African Studies, 47(2):159-162.

ROSENBLATT, PC 1993: Grief: The social context of private feelings. (In: Stroebe, MS; Stroebe, W \& Hansson, RO 1993: Handbook of bereavement. New York: Cambridge University Press. pp. 102111.)

SABLE, P 1992: Attachment, loss of spouse and disordered mourning. Families in Society : Journal of Contemporary Human Services, 73, May:266-273.
SCHULZ, R 1978: The psychology of death, dying and bereavement. Menlo Park: Addison-Wesley.

SIEGEL, JM \& KUYKENDAL, DH 1990: Loss, widowhood and psychological distress among the elderly. Journal of Consulting and Clinical Psychology, 58(5):519-524.

STROEBE, MS; STROEBE, W \& HANSSON, RO 1993: Handbook of bereavement. New York: Cambridge University Press.

VAN DEN HOONAARD, DK 1994: Paradise lost: Widowhood in a Florida retirement community. Journal of Ageing Studies, 8(2):121132.

WOODS, NF \& CATANZARO, M 1988: Nursing research: Theory and Practice. St. Louis: CV Mosby. 